1 A scanning ion imaging investigation into the micron-scale U-Pb systematics in a

2 complex lunar zircon

3

6

J. J. Bellucci ${ }^{1 *}$, M. J. Whitehouse ${ }^{1}$, A. A. Nemchin ${ }^{1,2}$, J. F. Snape ${ }^{1}$, R.T. Pidgeon ${ }^{2}$, M. Grange $^{2}$, S.M. Reddy ${ }^{2}$, N. Timms ${ }^{2}$

*Corresponding author, email address: jeremy.bellucci@gmail.com

${ }^{1}$ Department of Geosciences, Swedish Museum of Natural History, SE-104 05 Stockholm, Sweden

${ }^{2}$ Department of Applied Geology, Curtin University, Perth, WA 6845, Australia

\begin{abstract}
The full U-Pb isotopic systematics in a complex lunar zircon 'Pomegranate' from lunar impact breccia 73235 have been investigated by the development of a novel Secondary Ion Mass Spectrometry (SIMS) scanning ion imaging (SII) technique. This technique offers at least a four-fold increase in analytical spatial resolution over traditional SIMS analyses in zircon. Results from this study confirm the hypothesis that the Pomegranate zircon crystallized at $4.302 \pm 0.013 \mathrm{Ga}$ and experienced an impact that formed, U-enriched zircon around primary zircon cores at $4.184 \pm 0.007 \mathrm{Ga}(2 \sigma$, all uncertainties). The increase in spatial resolution offered by this technique has facilitated targeting of primary zircon that was previously inaccessible to conventional spot analyses. This approach has yielded results indicating that individual grains with a diffusive distance of less than $\sim 4 \mu \mathrm{m}$ have been reset to the young impact age, while individual grains with a diffusive distance larger than $\sim 6 \mu \mathrm{m}$ have retained the old crystallization age. Assuming a broad range in cooling rate of $0.5-50{ }^{\circ} \mathrm{C} /$ year, which has been observed in a suite of similar lunar breccias, a maximum localized temperature generated by the impact that reset small primary zircon and created new, high-U zircon is estimated to be between 1100 and $1280^{\circ} \mathrm{C}$.
\end{abstract}

\title{
Introduction
}

Zircon $\left(\mathrm{ZrSiO}_{4}\right)$ is one of the most robust and widely used geochronometers, in large part owing to its exceptional physical and chemical stability. It also has the advantage of hosting three independent decay chains to $\mathrm{Pb}$, two of which have a common parent element in $\mathrm{U}$. The robust physical characteristics of zircon have the potential to preserve geochemical and chronological information through multiple 
overprinting events postdating the original crystallization. However, this ability to preserve multiple event results in complexities often observed in the U-Pb system within individual zircon grains. As a result, the complex $\mathrm{U}-\mathrm{Pb}$ isotopic information of some individual zircon grains has been interpreted to represent partial recrystallization, replacement, and variable damage of crystal lattice by radioactive decay. Recent studies (e.g., Grange et al., 2013a; Kusiak et al., 2013a,b; Moser et al., 2011; Whitehouse et al., 2014) indicate that this variability and mixing can occur on the scale of a few nanometers to several micrometers. Consequently, the correct interpretation of $\mathrm{U}-\mathrm{Pb}$ data requires understanding of processes that might affect the chemistry and/or internal structure of zircon on an appropriate scale. When applied to zircon chronology in the samples from the Moon, where the fundamental objective is to constrain both igneous activity and the subsequent impact history of the lunar surface, the analytical challenge is to determine ages of recognized impact features that are often less than a few micrometers in the smallest dimension and may have irregular shapes (e.g., Grange et al., 2009; Grange et al., 2011; Grange et al., 2013a,b; Timms et al., 2012).

The small size and irregular shape of impact features in lunar zircon make them difficult, if not impossible to recognize and analyze for U-Pb systematics by conventional in situ methods, such as spot analysis using Secondary Ion Mass Spectrometry (SIMS) even at small spot sizes (e.g., Liu et al., 2011). Our aim in this manuscript is to present data obtained using a newly developed and tested SIMS scanning ion-imaging (SII) approach on the previously described "Pomegranate" zircon from lunar breccia 73235 (Grange et al., 2013b; Pidgeon et al., 2007; Smith et al., 1986). In contrast to earlier studies that measured only Pb-isotopes by SII, we 
have developed analytical and data processing protocols that resolve full $\mathrm{U}-\mathrm{Pb}$ systematics in irregularly shaped regions of interest with minimum dimension of $<5$ $\mu \mathrm{m}$.

\section{Sample details:}

Sample 73235 is an impact melt breccia with several mineral and lithic clasts (25\%) surrounded by an aphanitic matrix $(75 \%)$ that has been previously described in great detail (Pidgeon et al., 2007; Ryder 1993; Spudis and Ryder, 1981). The crew of Apollo 17 collected this sample from landslide material associated with the South Massif of the Taurus-Littrow Valley on the edge of the Serenitatis impact basin (Wolf, 1981). Due to the large range of shock features (e.g., shocked anorthosites and feldspathic impactites), rounded edges on mineral clasts, and bulk chemistry with a KREEP affinity, this sample has been interpreted as being part of the Serenitatis ejecta sequence that has incorporated both local and exotic materials (Dence et al., 1976; Hodges and Kushiro, 1974; Rhodes et al., 1974; Ryder, 1993; Spudis and Ryder, 1981; Wolf, 1981). Thin section 82 of sample 73235 contains a rounded clast of 75 broken fragments of zircon that resembles a cluster of pomegranate seeds (hence, the name commonly applied to this feature) located in a patch of 25 plagioclase crystals that have reacted with the surrounding matrix (Pidgeon et al., 2007; Smith et al., 1986). The bulk sample has an ${ }^{40} \mathrm{Ar} /{ }^{39} \mathrm{Ar}$ age of $3.90 \pm 0.04 / 0.08 \mathrm{Ga}$ and a $\mathrm{Rb}-\mathrm{Sr}$ whole rock isochron age of $4.02 \pm 0.01 \mathrm{Ga}$, which has been hypothesized to be the age of breccia formation (Nyquist et al., 1974; Ryder, 1993).

\section{Pomegranate Zircon:}


90 backscatter electron (BSE) imaging, secondary electron (SE) imaging, cathodoluminescence (CL), and electron backscatter diffraction mapping (EBSD), and its U-Pb isotopic systematics were studied by in situ SIMS U-Pb analyses utilizing a Köhler illuminated primary spot of $\sim 20 \mu \mathrm{m}$ in diameter (Grange et al., 2013; Pidgeon et al., 2007; Smith et al., 1986). The CL patterns of the larger grains within the aggregate have different but uniform CL density and retain primary, igneous sector zoning (Figure 1). However, these features are not traceable across fragments, which implies that the grains have been displaced and rotated during impact (Figure 1; after Pidgeon et al., 2007). Therefore, this zircon has been interpreted to have formed as a single large grain in an anorthosite, which subsequently experienced an impact or

100 impacts, resulting in fragmentation (Pidgeon et al., 2007; Smith et al., 1986).

101 Surrounding primary igneous zircon there is secondary zircon that is low in surface relief, dark in CL, non-crystalline (i.e., not indexed in EBSD, Figure 1 and Figure 2;

103 Grange et al., 2013; Pidgeon et al., 2007). and secondary zircon have ${ }^{207} \mathrm{~Pb} /{ }^{206} \mathrm{~Pb}$ ages of $4.315 \pm 0.015 \mathrm{Ga}$ and $4.187 \pm 0.011 \mathrm{Ga}$, respectively (uncertainties are $2 \sigma$, Pidgeon et al., 2007). U-Pb ages for this zircon do

108 not overlap the previously determined Ar-Ar (3.9 Ga) or the Rb-Sr ages of the bulk 109 sample (4.02 Ga; Nyquist et al., 1974; Ryder, 1993), which indicates that the thermal 110 pulse responsible for these ages had no significant effect on either the primary or 111 secondary zircon. The $U$ concentration in the secondary zircon $(86-215 \mu \mathrm{g} / \mathrm{g})$ is 112 significantly higher than that of the primary zircon (generally $14-106 \mu \mathrm{g} / \mathrm{g}$, Pidgeon et 113 al., 2007). The current interpretation on the formation of this zircon, taking into 
114 account the morphology of the zircon aggregate and $\mathrm{U}-\mathrm{Pb}$ ages of fragments and

115 high-U zircon, is that the fragments date the initial crystallization of zircon and its

116 anorthosite host, whereas the amorphous matrix was likely to have been formed by

117 cataclasis and frictional heating during the impact-induced shock that resulted in the

118 loss of all radiogenic $\mathrm{Pb}$ and addition of $\mathrm{U}$, thereby locally resetting the zircon $\mathrm{U}-\mathrm{Pb}$

119 system (Pidgeon et al., 2007). However, the source of the additional U remains

120 unexplained. During this impact event, the primary igneous zircon was fragmented,

121 rotated, displaced and engulfed by the newly formed, high-U impact-generated zircon.

The proposed impact resulted in a heterogeneous assemblage of relatively

124 large primary CL active grains, small primary CL active grains, and secondary high-U

125 zircon. The large primary grains and the areas of secondary zircon, which are large

126 enough for traditional SIMS analyses, were targeted in previous studies. However, the

127 majority of the secondary zircon shows irregular distribution between the fragments,

128 with individual patches that are generally smaller than accessible by conventional in

129 situ SIMS U-Pb spot analyses. Similarly, the small primary, CL active grains are

130 smaller than a conventional SIMS spot. In the present study we use the new SII

131 approach to image five areas that cover both primary and secondary zircon (Figure 1),

132 allowing for the investigation of the U-Pb systems at high spatial resolution $(<5 \mu \mathrm{m})$

133 in this highly complex zircon aggregate.

134

135 Analytical Methods

136 Zircon standards were analyzed in $25 \mathrm{~mm}$ diameter polished epoxy mounts

137 and the Pomegranate zircon in lunar sample 73235 was analyzed in a $25 \mathrm{~mm}$ diameter,

138 standard (30 $\mu \mathrm{m}$ thickness) petrographic thin section of the lunar breccia. A Tescan 
139 MIRA3 FE-SEM at the Microscopy and Microanalysis Facility (John de Laeter

140 Centre) at Curtin University in Perth, Western Australia, was used to image the

141 Pomegranate grain with $\mathrm{CL}$ and BSE at an acceleration voltage of $12 \mathrm{kV}$. Prior to

142 scanning ion image acquisition, the lunar thin section was cleaned in alternating

143 ultrasonic baths of ethanol and distilled water. After the sample was cleaned it was

144 coated with $30 \mathrm{~nm}$ of Au. Similar procedures were followed for the epoxy mount

145 containing standard zircon grains.

146 All SIMS SII analyses were performed using a CAMECA IMS1280 large-geometry

147 ion microprobe located at the NordSIMS facility, Swedish Museum of Natural

148 History, Stockholm, Sweden, closely following protocols modified from those

149 described by Kusiak et al. (2013a, b) and Whitehouse et al. (2014). Prior to the start of

150 each SII analysis, an area of $80 \times 80 \mu \mathrm{m}$ was sputtered for 10 minutes using a $\sim 20 \mu \mathrm{m}$,

$151 \sim 10 \mathrm{nA} \mathrm{O}_{2}^{-}$primary beam to effectively remove surface gold coating and minor

152 residual surface contamination. Additionally, this approach resulted in a uniform

153 implantation of oxygen in the upper surface of the zircon over the image area,

154 enhancing secondary ion yield. To obtain high spatial resolution for the $70 \mathrm{x} 70 \mu \mathrm{m}$

155 ion images of the standards and unknowns, a $50 \mu \mathrm{m}$ primary beam aperture was used,

156 resulting in a projected (Köhler) beam diameter of $\sim 5 \mu \mathrm{m}$ on the sample surface, a

157 beam current of $\sim 250 \mathrm{pA}$. This spot size, which corresponds to a surface area of 20

$158 \mu \mathrm{m}^{2}$, defines the minimum spatial resolution at which the technique can confidently

159 resolve individual, non-mixed zircon chemical domains.

160 The secondary ion beam from the rastered area was processed using the dynamic

161 transfer optical system (DTOS), a synchronized raster in the transfer section of the

162 instrument that deflects the ions back onto the ion optic axis of the instrument 
163

164

165

166

167

168

169

170

171

172

173

174

175

176

177

178

179

180

181

182

183

184

185

186

regardless of their original point of sputtering from the sample, allowing both image acquisition and collection of secondary ions at high mass resolution, in this case $\mathrm{M} / \Delta \mathrm{M}$ of 4860 . Secondary ion intensities of ${ }^{204} \mathrm{~Pb},{ }^{206} \mathrm{~Pb},{ }^{207} \mathrm{~Pb}$, and ${ }^{208} \mathrm{~Pb}$ were measured simultaneously using the multi-collector array, while ions of ${ }^{90} \mathrm{Zr}_{2}{ }^{16} \mathrm{O},{ }^{238} \mathrm{U}$ and ${ }^{238} \mathrm{U}^{16} \mathrm{O}_{2}$ were measured in subsequent peak hops. As with conventional SIMS U$\mathrm{Pb}$ in zircon analyses on the IMS1270/80 instruments, oxygen was introduced into the sample chamber increasing its pressure to $\sim 2 \times 10^{-5}$ mbar, effectively doubling $\mathrm{Pb}$ sensitivity (Schuhmacher et al., 1993). All ion-counting detectors used in this study were low-noise discrete dynode Hamamatsu 416 electron multipliers; typical backgrounds of $<0.005$ cps obviating the need for any background correction.

Prior to image acquisition, the secondary ion beam was centered in the field aperture, optimized for maximum energy distribution in a $45 \mathrm{eV}$ energy window, and mass calibrated using the zircon matrix ${ }^{90} \mathrm{Zr}_{2}{ }^{16} \mathrm{O}$ signal. Count times for the ions of ${ }^{90} \mathrm{Zr}_{2}{ }^{16} \mathrm{O}$, simultaneous $\mathrm{Pb}$ isotopes, ${ }^{238} \mathrm{U}$, and ${ }^{238} \mathrm{U}^{16} \mathrm{O}_{2}$ were 2, 12, 5, and 2 seconds, respectively, and images were integrated over 60 scans, resulting in a total analysis time of 34 minutes. ${ }^{90} \mathrm{Zr}_{2}{ }^{16} \mathrm{O},{ }^{238} \mathrm{U}$, and ${ }^{238} \mathrm{U}^{16} \mathrm{O}_{2}$ ions were measured in the same detector as the ${ }^{208} \mathrm{~Pb}$ ions in order to minimize aging on detectors used for the critical radiogenic $\mathrm{Pb}$ isotopes, ${ }^{206} \mathrm{~Pb}$ and ${ }^{207} \mathrm{~Pb}$, as well as unradiogenic ${ }^{204} \mathrm{~Pb}$.

Images were processed using the CAMECA WinImage2 software package. Regions of interest (ROIs) were selected in each of the five Pomegranate images. ROIs were selected based on the 'hot spots' in ${ }^{206} \mathrm{~Pb}$ images for each Pomegranate image (Figure 3). These hotspots correspond to the impact-generated zircon that have dark CL and are low relief in SE images, and have very little crystallinity (Figure 2). Additionally, several ROIs were selected in the primary zircon. The same ROI outlines were then 
applied to two images of the 91500 zircon standard and one image of an external

188 zircon standard, Temora 2. Once the ROIs were determined for each image, the 189 isotope ratios of ${ }^{207} \mathrm{~Pb} /{ }^{206} \mathrm{~Pb},{ }^{208} \mathrm{~Pb} /{ }^{206} \mathrm{~Pb},{ }^{204} \mathrm{~Pb} /{ }^{206} \mathrm{~Pb},{ }^{206} \mathrm{~Pb} /{ }^{238} \mathrm{U},{ }^{238} \mathrm{U}^{16} \mathrm{O}_{2} /{ }^{238} \mathrm{U}$, and

$190{ }^{90} \mathrm{Zr}_{2}{ }^{16} \mathrm{O} /{ }^{238} \mathrm{U}$ were calculated in WinImage2 and exported to Microsoft Excel where 191 all isotope ratios were corrected for gain differences between the electron multipliers 192 and $\mathrm{U} / \mathrm{Pb}$ elemental fractionation as described below.

A single, linear correction factor that accounts for $\mathrm{Pb}$ isotope mass

194 fractionation and gain differences between electron multipliers was determined by 195 performing conventional spot analyses of USGS basaltic glass reference material 196 BCR-2G $(\sim 11 \mu \mathrm{g} / \mathrm{g} \mathrm{Pb})$ before the imaging session, following the methods described 197 by Bellucci et al. (2015) and Whitehouse et al. (2005), using an $\sim 20 \mu \mathrm{m}, \sim 10 \mathrm{nA} \mathrm{O}_{2}^{-}$ 198 primary beam. All spot analyses were conducted in multi-collector mode at a mass resolution of $4860(\mathrm{M} / \Delta \mathrm{M})$, using an NMR field sensor in regulation mode to control 200 the stability of the magnetic field. Gain correction values were then determined by 201 comparison to the accepted $\mathrm{Pb}$ isotope ratios for BCR-2G (Woodhead and Hergt, 202 2000). Since $\mathrm{Pb}$ isotope fractionation is effectively non-existent between different 203 materials in SIMS Pb isotope analysis, typically being within the level of individual 204 analytical uncertainties (Shimizu and Hart, 1982), this correction is all that is needed 205 to account for gain/mass fractionation differences in $\mathrm{Pb}$ isotopic ratios during multi206 collector SIMS analyses. External precision in this session for ratios ${ }^{207} \mathrm{~Pb} /{ }^{206} \mathrm{~Pb}$, $207{ }^{208} \mathrm{~Pb} /{ }^{206} \mathrm{~Pb}$, and ${ }^{204} \mathrm{~Pb} /{ }^{206} \mathrm{~Pb}$ was $0.5 \%, 0.4 \%$, and $0.6 \%$, respectively $(2 \sigma)$. This 208 external precision was propagated through to all unknown $\mathrm{Pb}$ isotopic ratios.

209 Determining the correct ${ }^{238} \mathrm{U} /{ }^{206} \mathrm{~Pb}$ ratio from the secondary ion elemental210 ratio $\left({ }^{238} \mathrm{U}^{+} / 206 \mathrm{~Pb}^{+}\right)$is the most important factor for accurate U-Pb age determinations 
211 (e.g., Jeon and Whitehouse, 2015). In conventional spot analyses, factors that affect

212 this ratio are a result of the combination of variations in sample chamber pressure, 213 sample surface(s) irregularities, and changing primary beam conditions

214 (shape/intensity). Since the goal for this study is to determine the spatially resolved U-

$215 \mathrm{~Pb}$ systematics, an examination of how the $\mathrm{U} / \mathrm{Pb}$ ratio varies across the image is 216 critical.

The simplest way of correcting for $\mathrm{U} / \mathrm{Pb}$ fractionation uses the ${ }^{206} \mathrm{~Pb} /{ }^{238} \mathrm{U}^{16} \mathrm{O}_{2}$ 218 ratio, since $\mathrm{UO}_{2}$ has the most similar energy distribution in a secondary ion beam to $219 \mathrm{~Pb}$ (Jeon and Whitehouse, 2015; Stern 2000; Stern and Amelin, 2003). The $220{ }^{206} \mathrm{~Pb} /{ }^{238} \mathrm{U}^{16} \mathrm{O}_{2}$ was determined for each ROI in each image, after correcting for gain 221 differences between the detector used for ${ }^{208} \mathrm{~Pb}$ and ${ }^{206} \mathrm{~Pb}$, a ROI-specific correction 222 factor to convert ${ }^{206} \mathrm{~Pb} /{ }^{238} \mathrm{U}^{16} \mathrm{O}_{2}$ to ${ }^{206} \mathrm{~Pb} /{ }^{238} \mathrm{U}$ was calculated by averaging two 223 different analyses of zircon 91500 using the same ROI, assuming an accepted age of $2241065 \mathrm{Ma}$ (Wiedenbeck et al., 1995). This correction factor was then applied to each 225 specific unknown ROI, compensating for any $\mathrm{U} / \mathrm{Pb}$ fractionation differences across 226 the imaged area. The accuracy of the fractionation factor determined from 91500 was 227 assessed by applying the fractionation factor for each ROI to an image of the 228 secondary zircon standard, Temora 2 (Figure 4). The uncertainty (std. dev.) in the 229 average between the two 91500 ROIs was propagated in quadrature through to the 230 final, corrected $\mathrm{U} / \mathrm{Pb}$ ratios.

In summary, the final, corrected isotopic ratios are a result of an external gain 232 and external $\mathrm{U} / \mathrm{Pb}$ correction and the reported uncertainty thus combines Poisson's 233 counting statistics (internal uncertainty), the external gain, and the external $\mathrm{U} / \mathrm{Pb}$ 234 correction. Lastly, common $\mathrm{Pb}$ (given in Table 1 as $\mathrm{f}_{206} \%$ ), which likely results 
235 primarily from sample preparation, was monitored using ${ }^{204} \mathrm{~Pb}$ and corrected 236 assuming the present-day terrestrial $\mathrm{Pb}$ composition of Stacey and Kramers (1975). 237 After the gain, $\mathrm{U} / \mathrm{Pb}$ fractionation, and common $\mathrm{Pb}$ corrections were made for each 238 ROI, its $\mathrm{U}$ and $\mathrm{Pb}$ concentrations, ${ }^{207} \mathrm{~Pb} /{ }^{206} \mathrm{~Pb}$ and ${ }^{206} \mathrm{~Pb} /{ }^{238} \mathrm{U}$ ages were calculated 239 (ages assuming the U decay constant recommendation of Steiger and Jäger, 1977), 240 and weighted average calculations and concordia diagrams were made with Isoplot 2414.15 (Ludwig, 2012).

\section{Results}

244 Results for all corrected ratios, common $\mathrm{Pb}$ correction (resulting from any 245 residual laboratory contamination), $\mathrm{U}$ concentrations and calculated $\mathrm{Th} / \mathrm{U}$ ratios (from 246 measured ${ }^{208} \mathrm{~Pb} /{ }^{206} \mathrm{~Pb}$ and age) for each image and corresponding ROIs for Temora 2 247 and Pomegranate (Figure 3) are presented in Table 1. Results from the measured $248{ }^{206} \mathrm{~Pb} /{ }^{238} \mathrm{U}^{16} \mathrm{O}_{2}$ for the two sequential 91500 images (blue and red bars), concordia 249 diagrams, and weighted ${ }^{206} \mathrm{~Pb} /{ }^{238} \mathrm{U}$ ages for Temora 2 are shown in Figure 4. All of 250 the individual calculated ages for Temora 2 are within uncertainty of the accepted $251{ }^{206} \mathrm{~Pb} /{ }^{238} \mathrm{U}$ age of $416.8 \pm 1.3 \mathrm{Ma}$ (Black et al., 2004), but are systematically older than 252 the accepted value and have variable levels of discordancy, which will be discussed in 253 the following section. Concordia diagrams for all Pomegranate ROIs are presented in

254 Figure 5; similar to the Temora 2 analyses, some analyses are discordant outside of 255 uncertainty and speculation on the origins of this discordancy will be addressed in the 256 discussion section. 
261 similar $(\sim 0.15)$ but shows some dependence on location of each ROI in the image 262 (Figure 3 and 4). Most notably, the right-hand side of all of images has a lower $263{ }^{206} \mathrm{~Pb} /{ }^{238} \mathrm{U}^{16} \mathrm{O}_{2}$ ratio than the center/left sides of the images (e.g., Image $3 \mathrm{ROI}-2$ ). The 264 decrease in ${ }^{206} \mathrm{~Pb} /{ }^{238} \mathrm{U}^{16} \mathrm{O}_{2}$ ratio is likely due to the incoming primary beam traversing 265 over areas where the gold coating has been removed. Specifically, since the primary 266 beam enters from the left of the image, it travels a greater distance over a non-gold 267 coated surface to reach the right side than the left side of the image. A similar $\mathrm{Pb} / \mathrm{U}$ 268 bias effect has been observed when spot analyses are performed to the right of 269 previous analyses. Despite these small differences in ${ }^{206} \mathrm{~Pb} /{ }^{238} \mathrm{U}^{16} \mathrm{O}_{2}$, using the average $270{ }^{206} \mathrm{~Pb} /{ }^{238} \mathrm{U}^{16} \mathrm{O}_{2}$ ratio for each ROI from the calibration standard, then applying that 271 correction to the unknown, identical ROI, defines a set of statistically 272 indistinguishable ${ }^{206} \mathrm{~Pb} /{ }^{238} \mathrm{U}$ ages in Temora 2 regardless of location on the image. 273 When combined into a weighted mean, these data yield robust statistics for each 274 image (i.e., MSWD $<1, \mathrm{P}>0.75$ ) indicating a statistically identical population. 275 However, for each image the ${ }^{206} \mathrm{~Pb} /{ }^{238} \mathrm{U}$ age in Temora 2 is slightly older, while 276 within error, of the accepted age of $417 \mathrm{Ma}$, with a maximum of difference of $\sim 5 \%$ 277 seen in the weighted averages of the ROIs from image 5 (Figure 4).

\section{Concordance, accuracy, precision, and potential limitations}

The calculated ${ }^{206} \mathrm{~Pb} /{ }^{238} \mathrm{U}$ ages for Temora 2 measured here are systematically

280 older by a small amount. Despite the systematic bias, all individual Temora 2 analyses 281 are within $2 \sigma$ uncertainty of concordia and the accepted age and for the weighted 282 average for each image (Figure 4). However, if all Temora 2 ROIs are pooled it 283 results in a ${ }^{206} \mathrm{~Pb} /{ }^{238} \mathrm{U}$ age of $429 \pm 7 \mathrm{Ma}(2 \sigma)$, which is outside of uncertainty of the 
284 accepted age of $416.8 \pm 1.3$ Ma. Given the systematic offset, pooling of ${ }^{206} \mathrm{~Pb} /{ }^{238} \mathrm{U}$ 285 ages is not recommended using the method described here. This limits the potential 286 application of a single ROI U-Pb analyses because in small areas the precision can be 287 significantly worse than a traditional SIMS analysis, depending on size of the area and 288 counting statistics.

289 The origin of the systematic offset could be a result of a small error in the 290 actual ${ }^{206} \mathrm{~Pb} /{ }^{238} \mathrm{U}$ age of 91500 for the grains used for calibration. Isotope dilution 291 TIMS analyses of 91500 indicate that some pieces of 91500 are discordant 292 corresponding to $0.5 \% \mathrm{~Pb}$ loss (Wiedenbeck et al., 1995). Another potential 293 explanation for discordance is that there could be relief differences between standard 294 mounts and grains embedded in thin sections. However, the likeliest possibility is 295 having too few standard 91500 images when compared to conventional $\mathrm{U}-\mathrm{Pb}$ in 296 zircon analyses. During traditional U-Pb in zircon analyses, there are at least 6-8 U-Pb 297 calibration standards, often many more. Having only two standards reduces the ability 298 to recognize and filter out a potential outlier standard. As such, any future $\mathrm{U}-\mathrm{Pb}$ ion 299 imaging studies need to have significantly more primary and ideally secondary 300 standards to ensure accuracy in pooled ${ }^{206} \mathrm{~Pb} /{ }^{238} \mathrm{U}$ ages. However, for this work, the 301 small offset in ${ }^{206} \mathrm{~Pb} /{ }^{238} \mathrm{U}$ is not significant, because it does not affect ages calculated 302 from ${ }^{207} \mathrm{~Pb} /{ }^{206} \mathrm{~Pb}$ ratios, which are used to access chronology in old (including lunar) 303 zircon because of the improved accuracy.

\section{U-Pb systematics and ages in Pomegranate zircon}

Regardless of textural context, statistically pooling all ${ }^{207} \mathrm{~Pb} /{ }^{206} \mathrm{~Pb}$ ages into the

307 oldest and youngest statistically equal but independent populations (weighted 
averages of MSWD $<1.5$ and $\mathrm{P}>0.05)$ yields ages of $4.302 \pm 0.013(2 \sigma, \mathrm{MSWD}=$ $1.3, \mathrm{P}=0.16)$ and $4.184 \pm 0.007 \mathrm{Ga}(2 \sigma, \mathrm{MSWD}=0.71, \mathrm{P}=0.84$, Figure 6$)$. These

310 two statistically distinct ${ }^{207} \mathrm{~Pb} /{ }^{206} \mathrm{~Pb}$ age groups are in excellent agreement with the $3114.315 \pm 0.015$ and $4.187 \pm 0.011 \mathrm{Ga}$ ages determined by Pidgeon et al. (2007) and 312 Smith et al. (1986). The older age group encompasses large, CL-active grains, while 313 the younger group contains small, CL-active grains and high-U, secondary zircon. 314 This is a notable result given the measurements were performed using three different 315 instruments using two different techniques: spot analysis SHRIMP I and SHRIMP II, 316 and SII analysis on a CAMECA IMS1280 using the technique described here.

The secondary zircon clearly is enriched in both $\mathrm{U}$ and $\mathrm{Pb}$ and has a decreased 318 calculated $\mathrm{Th} / \mathrm{U}$ when compared to the primary host zircon (Table 1, Figures 2, 3, 7), 319 which is also in agreement with previous observations by Pidgeon et al. (2007) and 320 Smith et al. (1986). This zircon areas is clearly located on the crystal boundaries, 321 associated with dark areas in CL, and yield very low band contrast in EBSD patterns 322 indicating very little crystallinity, which supports the hypothesis that this high-U, low $323 \mathrm{Th} / \mathrm{U}$ (now amorphous) zircon was formed during an impact at $4.187 \mathrm{Ga}$.

Here the smallest ROI defined from the $\mathrm{U}$ and $\mathrm{Pb}$ enriched area (Image 5, 325 ROI-6) is $\sim 8 \mu \mathrm{m}^{2}$, which corresponds to an improvement of $40 \mathrm{x}$ in spatial resolution 326 over a $20 \mu \mathrm{m}$ spot typical in conventional SIMS analysis $\left(314 \mu \mathrm{m}^{2}\right)$. However, this 327 particular analysis is smaller than the spot size used $\left(20 \mu \mathrm{m}^{2}\right)$ and likely represents a 328 mixed $\mathrm{Pb}$ signal, though dominated by the targeted concentration 'hotspot'. 329 Additionally, the largest area here defined in Image 4, ROI-2 is $800 \mu \mathrm{m}^{2}$, which is 2.5 330 times larger than a traditional spot. This advantage over traditional spot analyses 331 could be widely applicable to homogenous, low $\mathrm{Pb}$ areas to increase counting 
statistics.

In addition to the two previously identified types of zircons (Grange et al., 334 2013; Pidgeon et al., 2007; and Smith et al., 1986), a third type is now recognized that 335 have low $\mathrm{U}$ concentrations and elevated $\mathrm{Th} / \mathrm{U}$ ratios, yet have been completely reset 336 to the younger age (Figure 7). Importantly, this third group is comprised of both the 337 secondary, high-U zircon (i.e., Image 1, ROIs-5, -6, -7, -8, -9, Figure 3) and CL active 338 primary zircon (Image 2, ROIs-1, -2, -3, -4, Image 5, ROI-1, Figure 3). The previous 339 hypothesis of impact generation very likely applies to the young zircon in Image 1 340 (Figure 3), due to their location on the rims of the primary zircon and correlation with 341 low relief, lack of CL, and featureless EBSD patterns. This cannot, however, explain 342 the CL active, reset primary zircon (in Images 2 and 5, Figure 3). The young ages 343 observed in these ROIs can only result from resetting of the U-Pb system due to 344 diffusion during the impact that formed the secondary zircon. ROIs-1, -2, -3, and -4 in Image 2 (Fig. 2) and ROI-1 in Image 5 all have low U 346 abundances $(12-65 \mu \mathrm{g} / \mathrm{g})$, high calculated $\mathrm{Th} / \mathrm{U}(0.35-0.6$, Table 1$)$, are active in $\mathrm{CL}$, 347 are surrounded by high $\mathrm{U}$ zircon, and are therefore assumed to be primary zircon, 348 despite being reset to the young $4.187 \mathrm{Ga}$ age (Figures 3 and 4). For Image 2, the 349 ROIs-1, $-2,-3,-4$, are very small with area dimensions of $77,49,76$, and $29 \mu \mathrm{m}^{2}$, 350 respectively, and are completely reset. Conversely, Image 3 ROI-4, which is similarly $351 \mathrm{CL}$ active but has the dimensions of $173 \mu \mathrm{m}^{2}$, was not reset. The smallest effective 352 diffusive distance (from the middle of the grain to the rim) in the reset primary grains 353 is $\sim 4 \mu \mathrm{m}$ and the smallest effective diffusive distance in the non-reset primary grain is $354 \sim 6 \mu \mathrm{m}$.

355 The closure temperature of a mineral - that is, the temperature at the time 
356 corresponding to its apparent age - is determined by grain size, diffusion coefficients,

357 mineral geometric factor, and cooling rate (e.g., Dodson et al., 1973). Therefore, the

358 localized temperature experienced by the impact-reset grains can be estimated making

359 the following assumptions: $\mathrm{Pb}$ diffusion coefficients in zircon (Cherniak and Watson,

360 2001), a spherical geometry factor, and a range in cooling rate of $0.5-50^{\circ} \mathrm{C} /$ year

361 (determined in multiple lunar impact breccias by Cushing et al., 1999). Figure 8

362 illustrates the effective diffusion radius vs. closure temperature in zircon based on the

363 range in cooling rates determined for other lunar breccias. The temperature range that

364 is capable of completely resetting the grains with a minimum effective diffusion

365 radius smaller than $4 \mu \mathrm{m}$ without significantly modifying grains larger than $6 \mu \mathrm{m}$ is

366 between $\sim 1100$ and $1280{ }^{\circ} \mathrm{C}$ (Figure 8 ). It is noteworthy that larger grains do not

367 show any measurable diffusive resetting and the boundary between impact generated

368 zircon and large primary zircon is extremely sharp (i.e., Image 3 ROI-3 and ROI-4).

369 This is most likely due to localized temperature/pressure variability associated with

370 the impact event that generated the impact zircon.

371 Conclusions

372 The new, extended scanning ion imaging technique facilitates a $\sim 4 \mathrm{x}$ increase

373 in spatial resolution for full U-Pb systematics, while being capable of accommodating

374 analysis domains of any user-defined shape and accessing the visual distribution of $U$

375 and $\mathrm{Pb}$ which is in contrast to full $\mathrm{U}-\mathrm{Pb}$ spot analyses, even when performed at $5 \mu \mathrm{m}$.

376 Application of this technique has allowed for the determination of accurate ${ }^{206} \mathrm{~Pb} /{ }^{238} \mathrm{U}$

377 age in Temora 2 zircon (within an individual ROI, at the $2 \sigma$ uncertainty level), and

378 the ${ }^{207} \mathrm{~Pb} /{ }^{206} \mathrm{~Pb}$ ages of three texturally and compositionally distinct types of domain

379 corresponding to primary, reset primary, and amorphous, impact generated zircon in

380 the Pomegranate aggregate from lunar sample 73235. Combined with previous data, 
381 the Pomegranate grains crystallized at $4.302 \pm 0.013 \mathrm{Ga}$ and experienced an impact

382 event that generated new, high-U zircon and reset primary zircons with a minimum 383 diffusive distance of $<6 \mu \mathrm{m}$ at $4.184 \pm 0.007 \mathrm{Ga}$ (errors $2 \sigma$ ). Assuming that localized

384 resetting of the $\mathrm{U}-\mathrm{Pb}$ system occurred by volume diffusion during a thermal pulse

385 associated with an impact event, a comparison of the extent of ${ }^{207} \mathrm{~Pb} /{ }^{206} \mathrm{~Pb}$ age 386 resetting with grain size (effective diffusion distance) in the primary zircon vs. 387 preserved primary zircon constrains the maximum localized temperature generated by 388 the impact to between 1100 and $1280{ }^{\circ} \mathrm{C}$. Diffusion modeling at this spatial resolution 389 would not have been possible using in situ SIMS conventional spot analysis 390 techniques. Lastly, this study demonstrates that this method could be widely 391 applicable to understanding isotope systematics in complex zircon as long as the 392 limitations discussed in this manuscript are taken into account. Given that this is 393 currently the only analytical technique that can resolve the spatial distribution of $U$, $394 \mathrm{~Pb}$, and the $\mathrm{U}-\mathrm{Pb}$ isotope systematics on the scale of $<5 \mu \mathrm{m}$ simultaneously, the 395 approach and future improvements outlined in this study could significantly enhance 396 what can be learned from complex zircon.

\section{Acknowledgements}

399 The authors would like to thank the astronauts of Apollo 17 for risking their 400 lives to retrieve the sample studied here. NASA is similarly thanked for curating, 401 preparing, and lending the sample section. The authors would like to thank Dr. 402 Richard Stern, an anonymous reviewer, and editor Dr. Klaus Mezger whose 403 comments helped improve the quality, accuracy, and presentation of this paper. This 404 work was funded by grants from the Knut and Alice Wallenberg Foundation 405 (2012.0097) and the Swedish Research Council (VR 621-2012-4370) to MJW and 
AAN. The Nordsim ion microprobe facility operates as a Nordic infrastructure. This

is Nordsim publication \#XYZ.

\section{References cited}

410 Bellucci, J.J., Nemchin, A.A., Whitehouse, M.J., Humayun, M., Hewins, R., and Zanda, B., 411 2015. Pb-isotopic evidence for an early, enriched crust on Mars. Earth and Planetary Science 412 Letters. 410, 34-41. DOI: 10.1016/j.eps1.2014.11.018

413 Black, L.P, Kamo, S.L., Allen, C.M., Davis, D.W., Aleinikoff, J.N., Valley, J.W., Mundil, R., 414 Campbell, I.H., Korsch, R.J., Williams, I.S., and Foudoulis, C. (2004) Improved 206Pb/238U 415 microprobe geochronology by the monitoring of a trace element-related matrix effect: 416 SHRIMP, ID-TIMS, ELA-ICP-MS, and oxygen isotope documentation for a series of zircon 417 standards. Chemical Geology, 2015, 115-140.

Cherniak DJ, Watson EB (2001) Pb diffusion in zircon. Chem Geol 172:5-24

420

421

422

423

424

425

426

427

428

429

430

431

432

433

434

435

436

437

438

439

440

441

442

443

444

445

446

447

Cushing, J.A., Taylor, G.J., Norman, M.D., and Keil, K. (1999) The granulitic impactite suite: Impact melts and metamorphic breccias of the early lunar crust. Meteor. \& Planetary Sicece 34, 185-195.

Dence, M.R., Grieve, A.F., Plant, A.G., 1976. Apollo 17 grey breccias and crustal composition in the Serenitatis Basin region. Proceedings of Lunar Science Conference VII, $1821-1832$.

Dodson, M.H., 1973. Closure temperature in cooling geochronological and petrological systems. Contrib. Mineralog. Petrol. 40, 259-274.

Grange M. L., Nemchin A. A., Pidgeon R. T., Timms N., Muhling J. R. and Kennedy A. K. (2009) Thermal history recorded by the Apollo 17 impact melt breccia 73217. Geochim. Cosmochim. Acta 73, 3093-3107.

Grange M. L., Nemchin A. A., Timms N., Pidgeon R. T. and Meyer C. (2011) Complex magmatic and impact history prior to 4.1 Ga recorded in zircon from Apollo 17 South Massif aphanitic breccia 73235. Geochim. Cosmochim. Acta 75, 2213-2232.

Grange, M. L., A. A. Nemchin, and R. T. Pidgeon (2013a), The effect of 1.9 and $1.4 \mathrm{Ga}$ impact events on $4.3 \mathrm{Ga}$ zircon and phosphate from an Apollo 15 melt breccia, J. Geophys. Res. Planets, 118, 2180-2197,

Grange, M.L., Pidgeon, R.T., Nemchin, A.A., Timms, N.E., Meyer, C. (2013b) Interpreting $\mathrm{U}-\mathrm{Pb}$ data from primary and secondary features in lunar zircon. Geochim. Cosmochim. Acta 101, 112-132.

Hodges, F.N.; Kushiro, I., 1974. Apollo 17 petrology and experimental differentiation sequences in model Moon compositions. Proc. Fifth Lunar Sci. Conf., Geochim. Cosmochim. Acta (Suppl. 5), 505-520.

Jeon, H. and Whitehouse, M.J. (2015) A critical evaluation of U-Pb calibration schemes used in SIMS zircon geochronology. Geostandards and Geoanalytical Research. DOI: $10.1111 / \mathrm{j} .1751-908 X .2014 .00325 . \mathrm{X}$ 
Kusiak, M. A. and Whitehouse, M. J. and Wilde, S. A. and Dunkley, D. J. and Menneken, M. and Nemchin, A. A. and Clark, C. (2013a). Changes in zircon chemistry during archean UHT metamorphism in the Napier complex, Antarctica. American Journal of Science. 313 (9): pp. 933-967

Kusiak M, Whitehouse MJ, Wilde S.A., Nemchin, A.A., Clark, C. (2013b) Mobilization of radiogenic $\mathrm{Pb}$ in zircon revealed by ion imaging: implications for early Earth geochronology. Geology 41(3): 291-294

Liu, Y., Li, X-H, Li, Q-L, Tang, G-Q, Yin, Q-Z. (2011) Precise U-Pb zircon dating at a scale of $<5$ micron by the CAMECA 1280 SIMS using a Gaussian illumination probe. Journal of Analytical Atomic Spectrometry. 26, 845-851.

Ludwig, K.R. 2012. User's Manual for Isoplot3.75: A Geochronological Toolkit for Microsoft Excel. Spec. Publ. 5 Berkeley Geochronological Center, 2012.

Meyer C., Williams I. S. and Compston W. (1996) Uranium-lead ages for lunar zircons: Evidence for a prolonged period of granophyre formation from 4.32 to $3.88 \mathrm{Ga}$. Meteoritics and Planetary Science 31, 370-387. http://dx.doi.org/10.1111/j.1945-5100.1996.tb02075.x.

Moser D. E., Cupelli C. L., Barker I., Flowers R. M., Bowman J. R., Wooden J. and Hart R. (2011) New shock phenomena for dating and reconstruction of large impact basins revealed by zircon microstructural (EBSD, CL), U-Pb and (U-Th)/He analysis of the Vredefort dome. Can. J. Earth Sci. 48, 117-139.

National Research Council (NRC) of the National Academies. (2007) The Scientific Context for Exploration of the Moon. National Academies Press, Washington, DC.

Nemchin A. A., Pidgeon R. T., Whitehouse M. J., Vaughan J. P. and Meyer C. (2008) SIMS $\mathrm{U}-\mathrm{Pb}$ study of zircon from Apollo 14 and 17 breccias: Implications for the evolution of lunar KREEP. Geochim. Cosmochim. Acta 72, 668-689. 475 http://dx.doi.org/10.1016/j.gca.2007.11.009.

476 Pidgeon R. T., Nemchin A. A., van Bronswijk W., Geisler T., Meyer C., Compston W. and Williams I. S. (2007) Complex history of a zircon aggregate from lunar breccia 73235. Geochim. Cosmochim. Acta 71, 1370-1381.

479 Rhodes, J.M., Rogers, K.V., Shih, C.-Y., Bansal, B.M., Nyquist, L.E., Wiesmann, H., 480 Hubbard, N.J., 1974. The relationship between geology and soil chemistry at the Apollo 481 landing site Proc. Fifth Lunar Sci. Conf., Geochim. Cosmochim. Acta (Suppl. 5), 1097-1117.

482 Ryder, G., 1993. Catalog of Apollo 17 rocks. vol. 1, National Aeronautics and Space 483 Administration, Lyndon B. Johnson Space Center Houston USA. JSC \#26088, pp. 410.

484 Schuhmacher M., de Chambost E., McKeegan K.D., Harrison T.M. and Migeon H.N. 485 (1993) In situ U/Pb dating of zircon with the CAMECA ims 1270. In: Benninghoven A., 486 Nihei Y., Shimizu R. and Werner H.W. (eds), Secondary ion mass spectrometry SIMS IX. 487 John Wiley (New York), 919-922.

488 Shimizu, N. and Hart, S.R. 1982. Isotope fractionation in secondary ion mass spectrometry. 489 Journal of Applied Physics 53, 1303

490

491 Smith J. M., Meyer C., Compston W. and Williams I. S. (1986) 73235,82 (Pomegranate): an 
assemblage of lunar zircon with unique overgrowth. 17th Lunar and Planetary Science Confer- ence. Houston. \#805-806 (abstr.).

Spudis, P.D., Ryder, G., 1981. Apollo 17 impact melts and their relation to the Serenitatis basin. In: Schultz, P.H., Merrill, R.B. (Eds.), Multi- ring basins: Formation and evolution; Proceedings of Lunar and Planetary Science Conference, XIIA, Lunar and Planetary Institute Houston, USA, pp. 133-148.

Stacey, J.S., Kramers, J.D., 1975. Approximation of terrestrial lead isotope evolution by a two-stage model. Earth Planet. Sci. Lett. 26, 207-221.

Steiger, R.H. and Jager, E. (1977). Subcommission on geochronology: Convention on the use of decay constants in geo- and cosmochronology. Earth and Planetary Science Letters 36(3): 359-362.

Stern R.A. (2000) The significance of secondary ion energy profiles for understanding interelement calibration curves in SIMS analyses of zircon and monazite. In: Woodhead J.D., Hergt J.M. and Noble W.P. (eds), Beyond 2000: New frontiers in isotope geoscience. Eastern Press (Lorne, Australia), 167- 170.

Stern R.A. and Amelin Y. (2003) Assessment of errors in SIMS zircon U-Pb geochronology using a natural zircon standard and NIST SRM 610 glass. Chemical Geology, 197, 111-142.

Timms N. E., Reddy S. M., Healy D., Nemchin A. A., Grange M. L., Pidgeon R. T. and Hart R. (2012) Resolution of impact- related microstructures in lunar zircon: a shock-deformation mechanism map. Meteorit. Planet. Sci. 47(1), 120-141.

Whitehouse, M.J., Kamber, B.S., Fedo, C.M., Lepland, A. 2005. Integrated Pb- and S- isotope investigation of sulphide minerals from the early Archean of southwest Greenland. Chemical Geology, 222, 112-131.

Whitehouse, M.J., Kumar, G.R.R., and Rimša, A. (2014) Behaviour of radiogenic $\mathrm{Pb}$ in zircon during ultrahigh-temperature metamorphism: an ion imaging and ion tomography case study from the Kerala Khondalite Belt, southern India. Contrib Mineral Petrol. 168:1042

Wiedenbeck M, Allé, P., Corfu, F., Griffen, W.L., Meier, M., Oberli, F., Quadt, A. Von, Roddick, J.C., and Spiegel, W. 1995. Three natural zircon standards for U-Th-Pb, Lu-Hf, Trace element, and REE analyses. Geostandards and Geoanalytical Research. 19:1-23.

Wolf, E.W. and others., 1981. The geologic investigation of the Taurus- Littros Valley: Apollo 17 landing site. US Geol Survey Prof. Paper, 1080, p. 280.

Woodhead, J.D. and Hergt, J.M. 2000. Pb-isotope analyses of USGS reference materials. Geostandards and Geoanalytical Research 24, 33-38.

Figure 1. Backscatter Electron (BSE) and cathodoluminescence (CL) images of Pomegranate zircon in lunar impact breccia 73235, previously described by Pidgeon et al., (2007). Areas of ion imaging analyses are marked by red squares that are $70 \mathrm{x}$ 
$53170 \mu \mathrm{m}$. Bright spots in the BSE image are remnants of the Au coating used during

532 SIMS analyses.

533

534 Figure 2. ${ }^{90} \mathrm{Zr}_{2}{ }^{16} \mathrm{O}$ and ${ }^{206} \mathrm{~Pb}$ ion images, EBSD and Secondary Electron (SE) images, 535 of primary igneous ( $\mathrm{Zr}$ 1) and secondary high-U zircon ( $\mathrm{Zr} 2)$, corresponding to 536 Image 1 of Figure 1. $\mathrm{Zr} 2$ is clearly enriched in ${ }^{206} \mathrm{~Pb}$ compared to $\mathrm{Zr} 1$, despite its 537 younger age. SE and EBSD images from Grange et al. (2013).

538

539 Figure 3. Ion images of ${ }^{90} \mathrm{Zr}_{2}{ }^{16} \mathrm{O},{ }^{238} \mathrm{U},{ }^{206} \mathrm{~Pb}, \mathrm{CL}$, and selected regions of interest 540 (ROIs) superimposed on ${ }^{206} \mathrm{~Pb}$ ion image.

542 Figure 4. Measured ${ }^{206} \mathrm{~Pb} /{ }^{238} \mathrm{U}^{16} \mathrm{O}_{2}$ in two 91500 images (ROIs are given by number 543 above blue and red bars with values for first and second images of 91500, 544 respectively), corrected Temora 2 concordia diagrams, and weighted average of $545{ }^{206} \mathrm{~Pb} /{ }^{238} \mathrm{U}$ age in Temora 2. Green dashed line in weighted average calculation is the 546 accepted value for the ${ }^{206} \mathrm{~Pb} /{ }^{238} \mathrm{U}$ age of Temora 2 (417 Ma, Black et al., 2004).

548 Figure 5. Concordia diagrams for all ROIs in Pomegranate zircon. Red ellipses are 549 the statistically younger population, while black ellipses are the statistically older 550 population.

552 Figure 6. ${ }^{207} \mathrm{~Pb} /{ }^{206} \mathrm{~Pb}$ age weighted averages for the primary zircon (A) and reset 553 zircon (B). Dashed green lines are values determined by traditional $\mathrm{U}-\mathrm{Pb}$ analyses by 554 Pidgeon et al. (2007) and Smith et al. (1986). 
556 Figure 7. $\mathrm{U}$ concentration in $\mu \mathrm{g} / \mathrm{g}$ and calculated $\mathrm{Th} / \mathrm{U}$ vs. ${ }^{207} \mathrm{~Pb} /{ }^{206} \mathrm{~Pb}$ age. Grey field 557 represents previously determined values by traditional in situ methods from Pidgeon 558 et al. (2007) and Smith et al. (1986). Zircon 1 field is dominated by old, CL active 559 grains. Zircon 2 field is dominated by young, CL inactive, high-U grains. Zircon 3 560 field is a combination of low $\mathrm{U}, \mathrm{CL}$ active/inactive, and young ages.

562 Figure 8. Effective diffusive distance in micrometers vs. closure temperature in ${ }^{\circ} \mathrm{C}$ 563 determined by the method of Dodson (1973). Closure T was calculated using $\mathrm{Pb}$ 564 diffusion coefficients (Cherniak and Watson, 2001), assuming a spherical geometry, 565 and a range in closure temperatures observed in other lunar breccias (Cushing et al., 566 1999). 

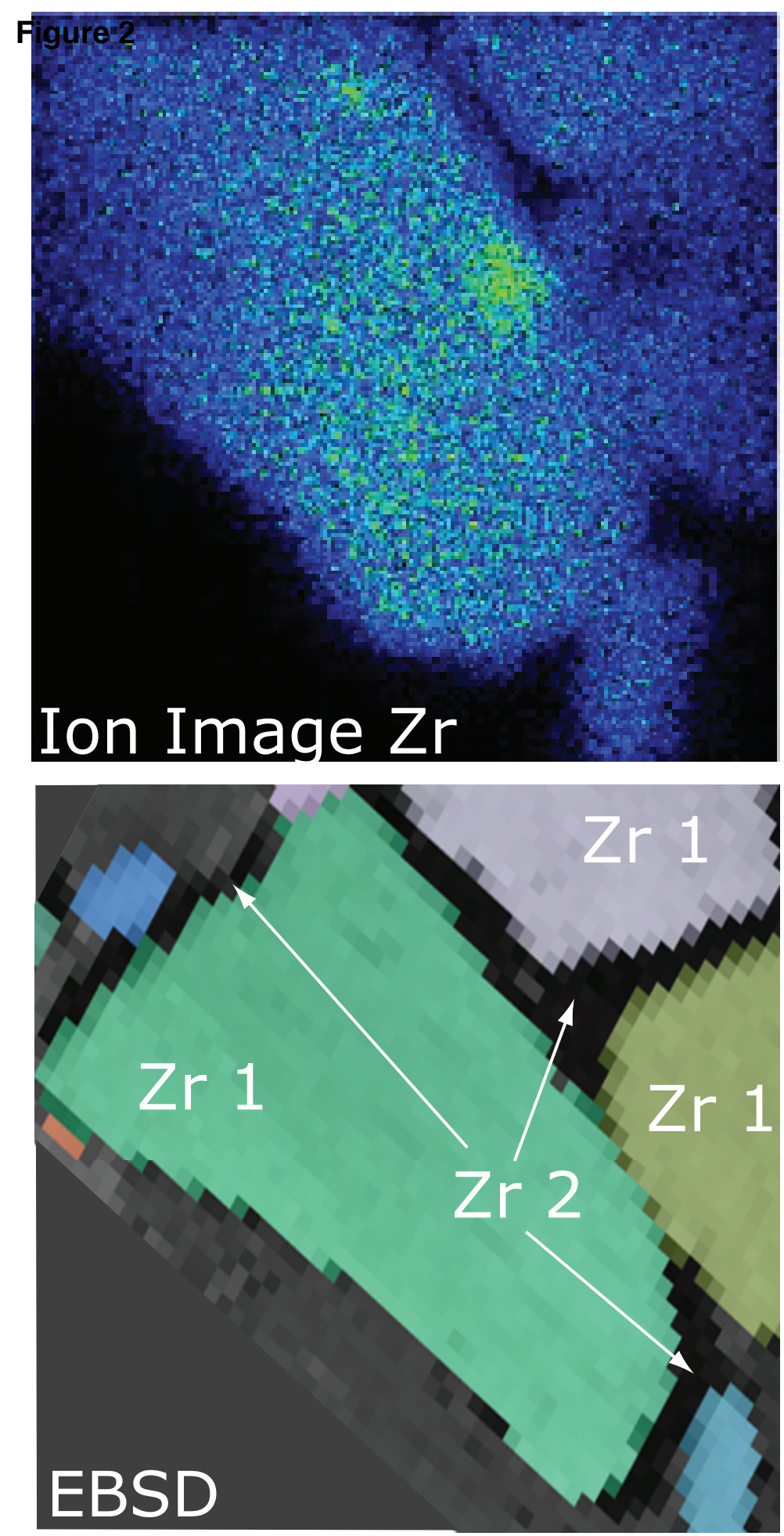

Zircon orientation

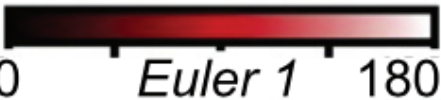

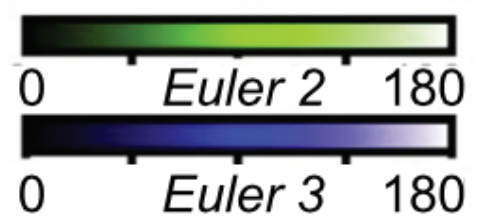
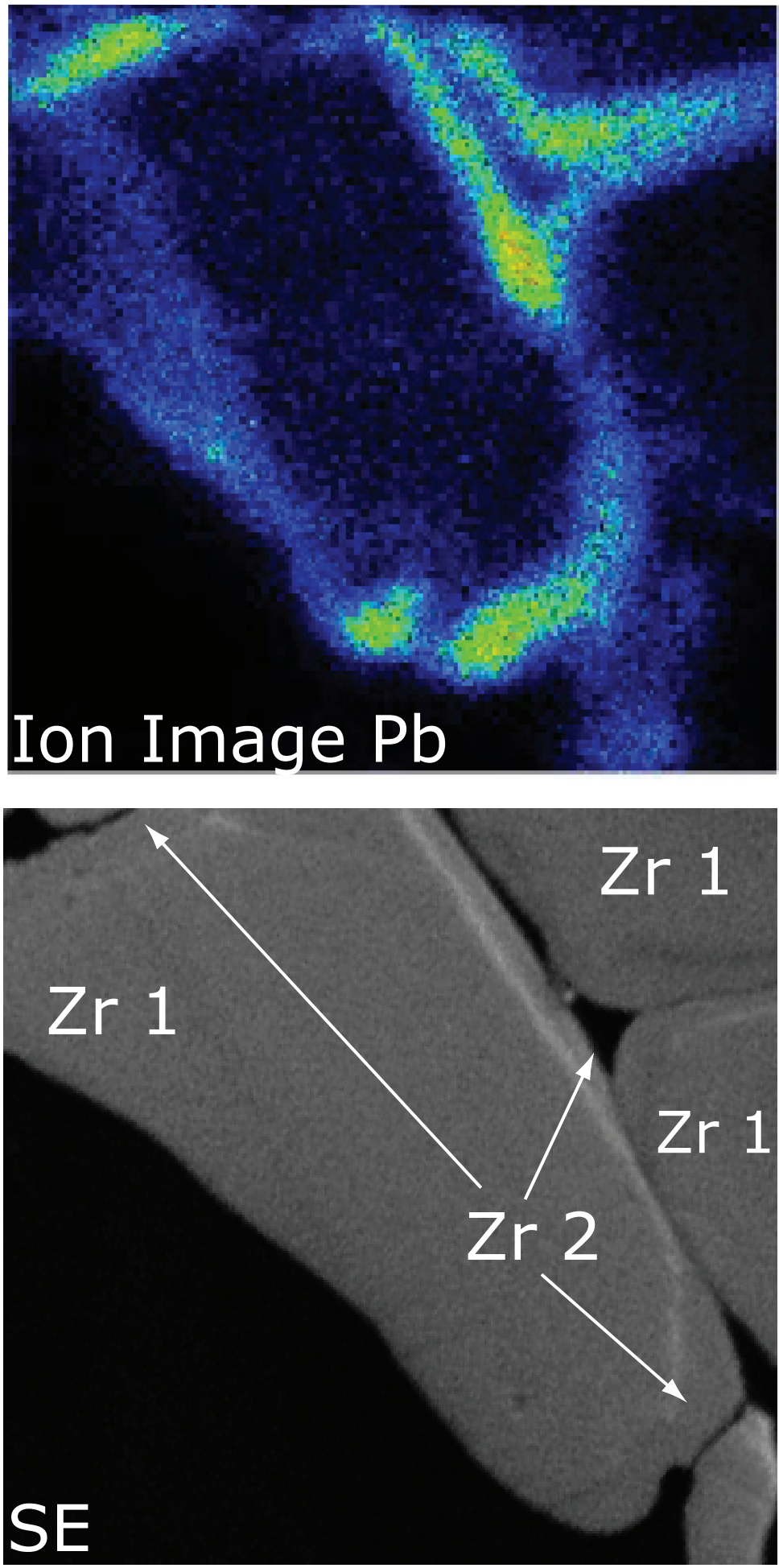

$\sim 70 \mu \mathrm{m}$ 

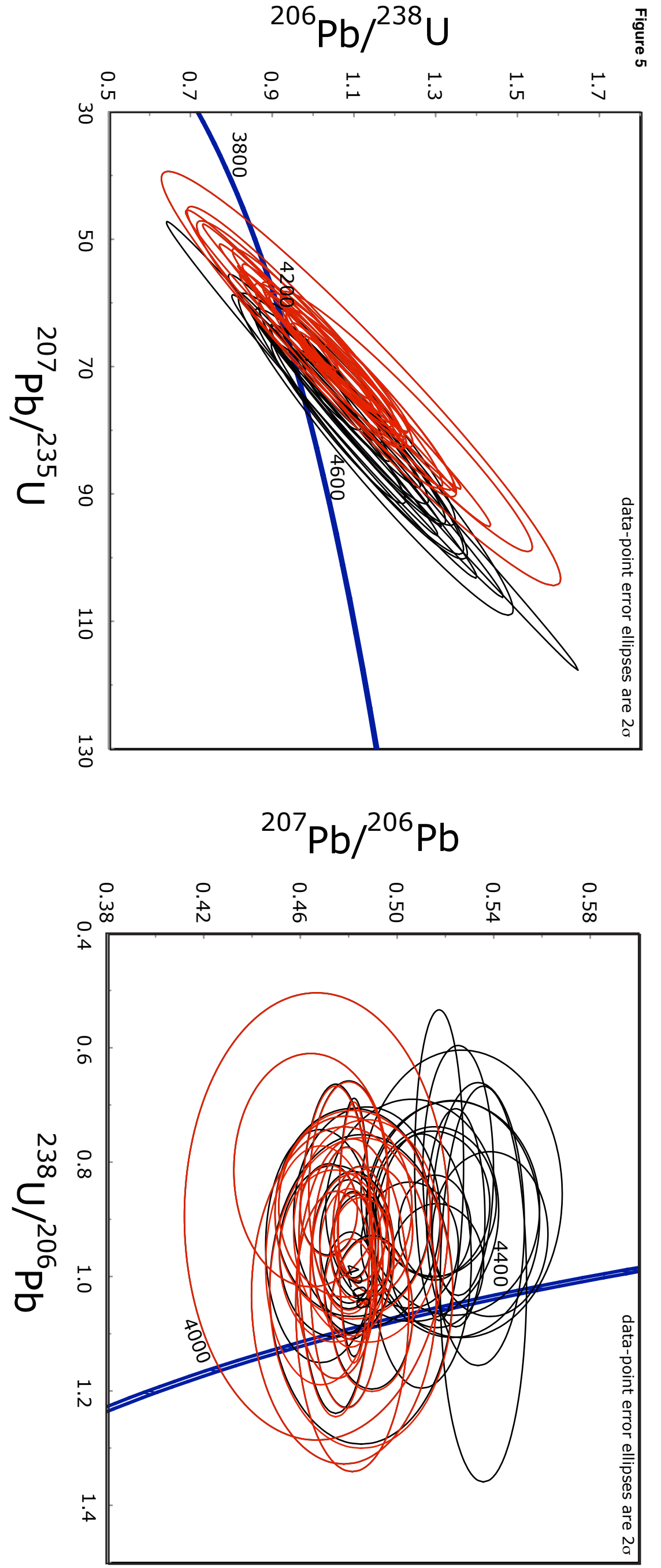


\section{${ }^{207} \mathrm{~Pb} /{ }^{206} \mathrm{~Pb}$ Age in Ma}

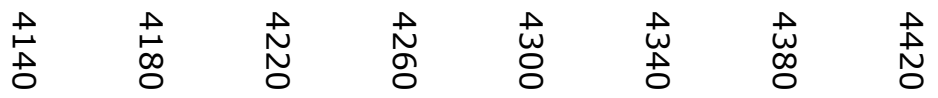

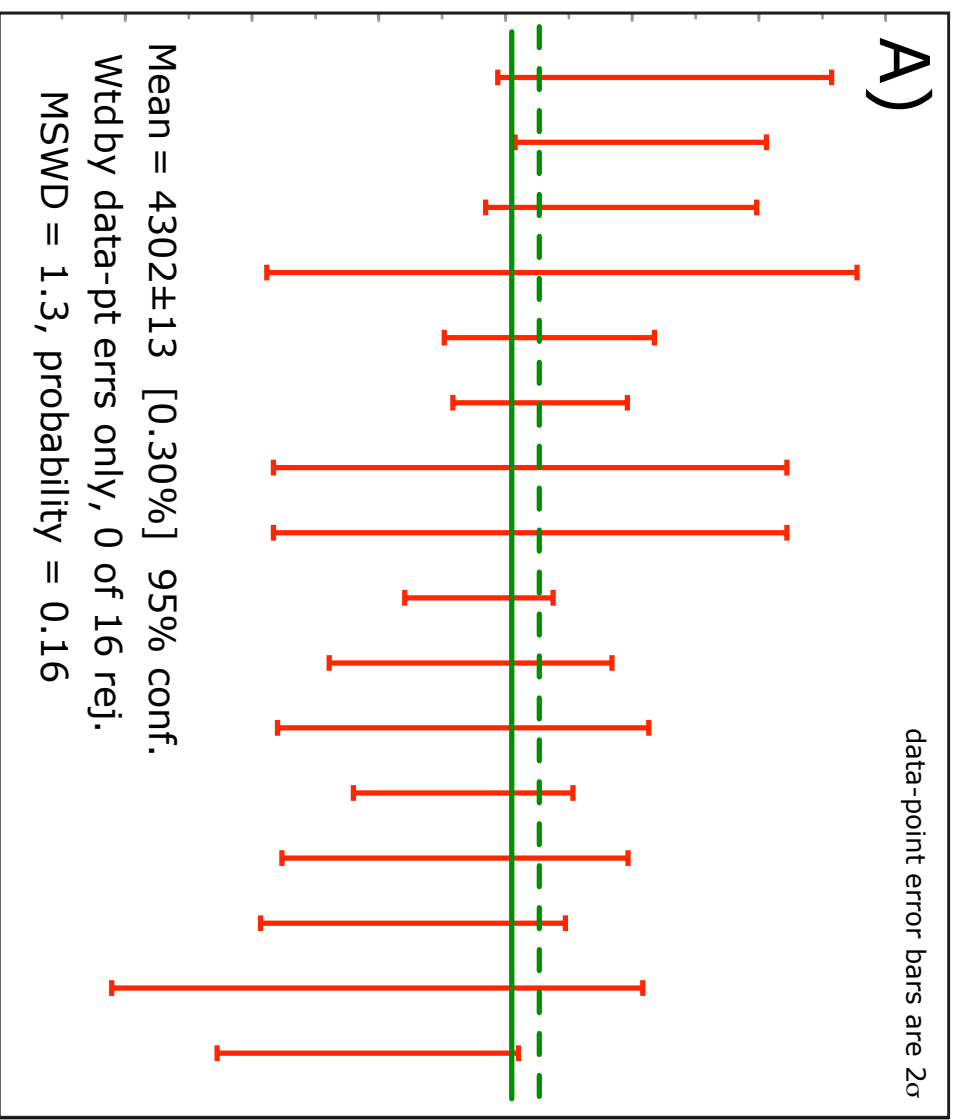

${ }^{207} \mathrm{~Pb} /{ }^{206} \mathrm{~Pb}$ Age in $\mathrm{Ma}$

岕

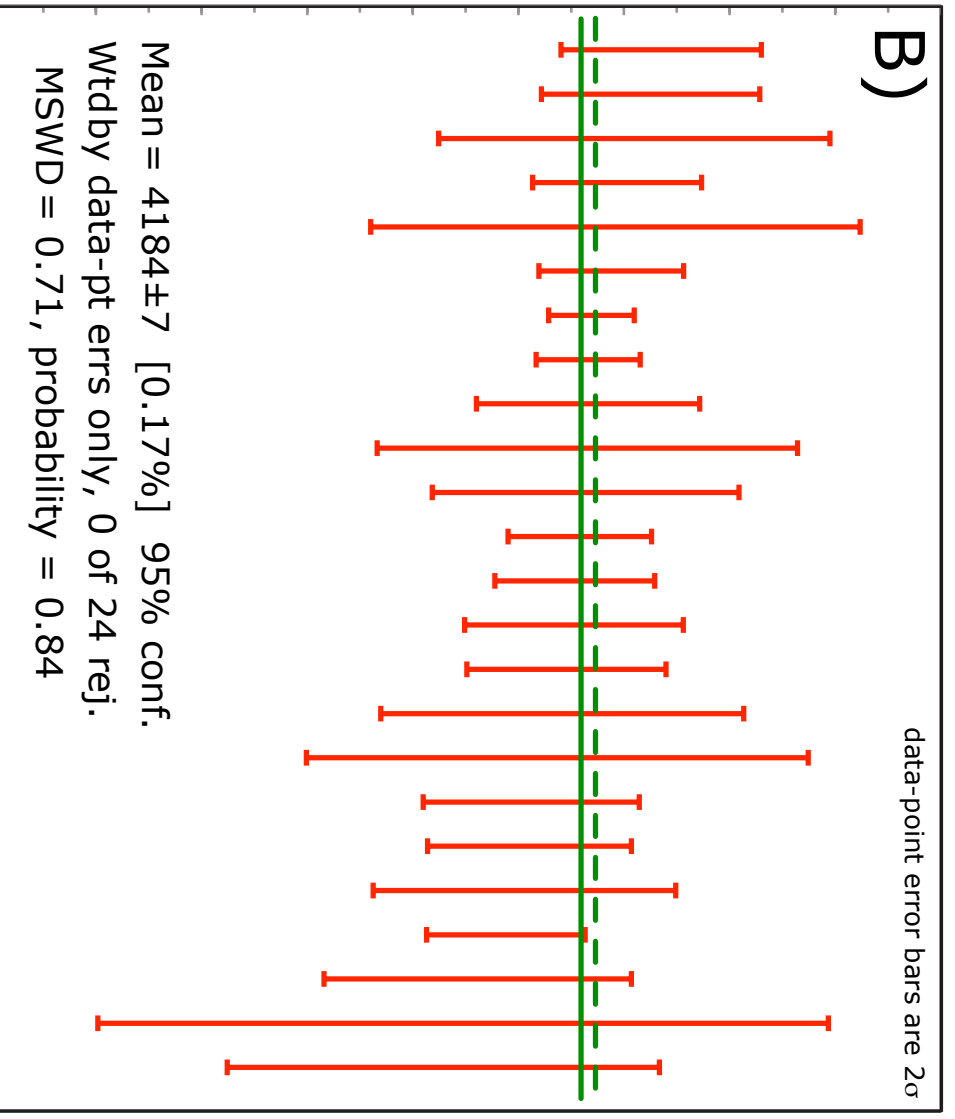


Figure 7

0.9

$\underset{\mathcal{U}}{\circlearrowright} 0.8$

$\begin{array}{ll}+\pi & 0.7\end{array}$

즌 0.7

근 0.6

J 0.5

U

$\supset 0.4$

0.3

F

0.2

0.1
8

$\diamond$ Zircon 1

A Zircon 2

O Zircon 3

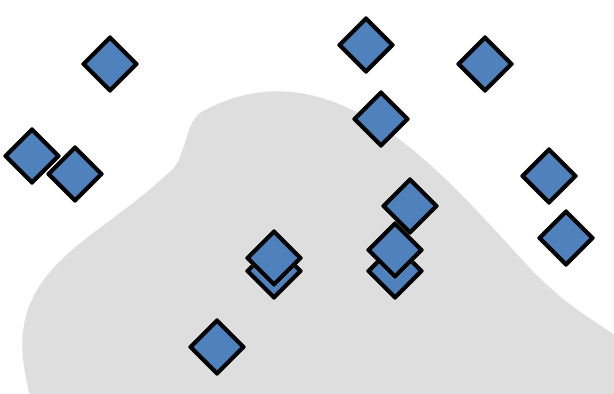

O

$0_{0} \quad 2$

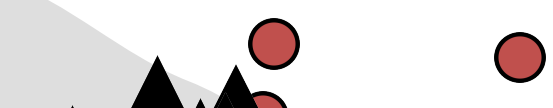

350

300

or

के 250

0
.
5

200

150

100

50

0

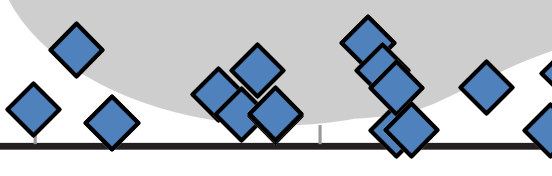

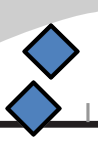

$\circ 0^{\circ}$

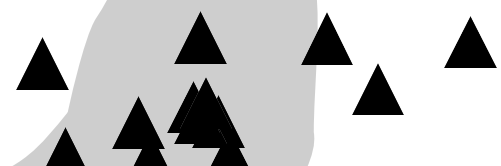

4400

4300

4250

${ }^{207} \mathrm{~Pb} /{ }^{206} \mathrm{~Pb}$ Age in $\mathrm{Ma}$ 


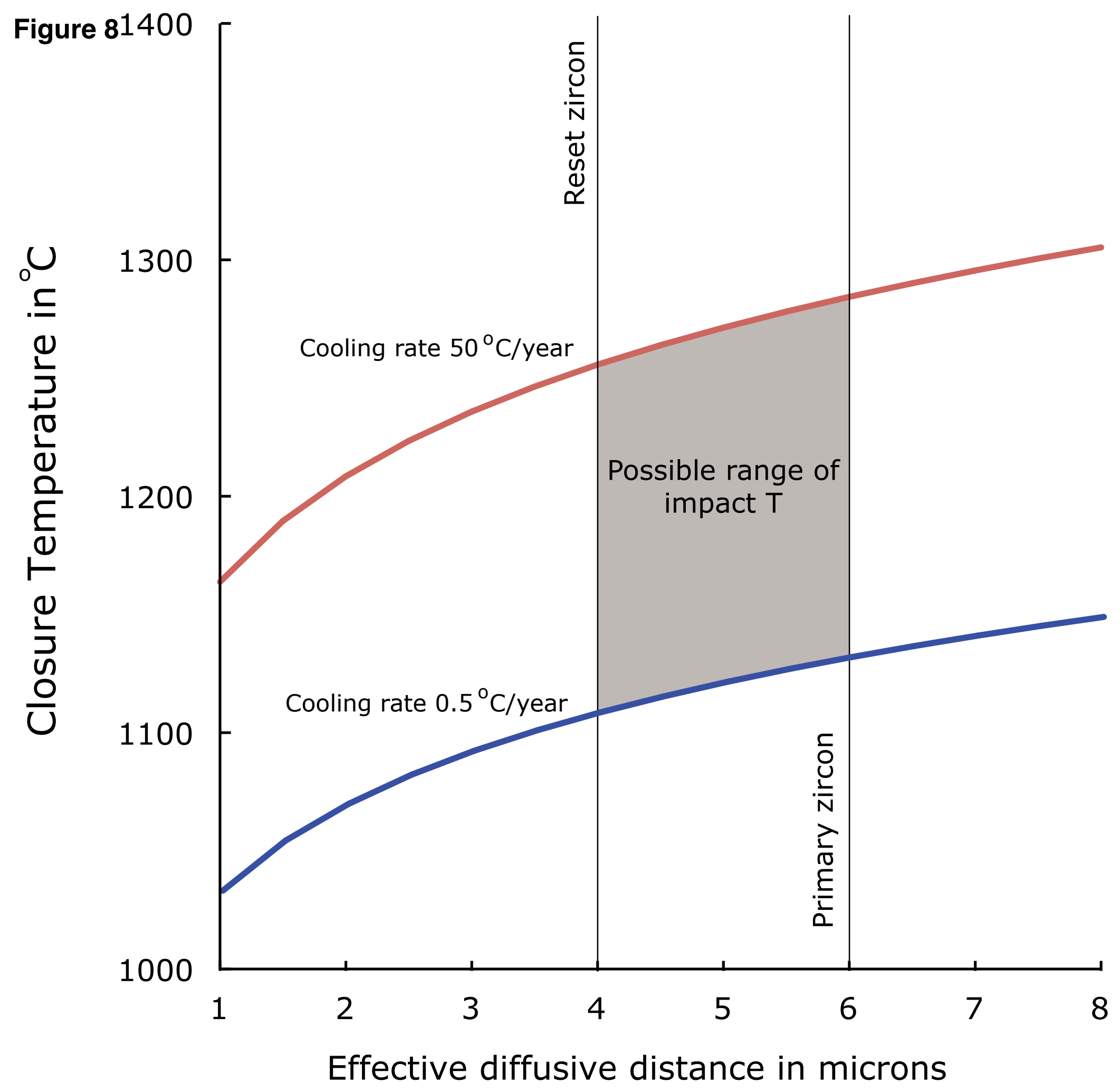




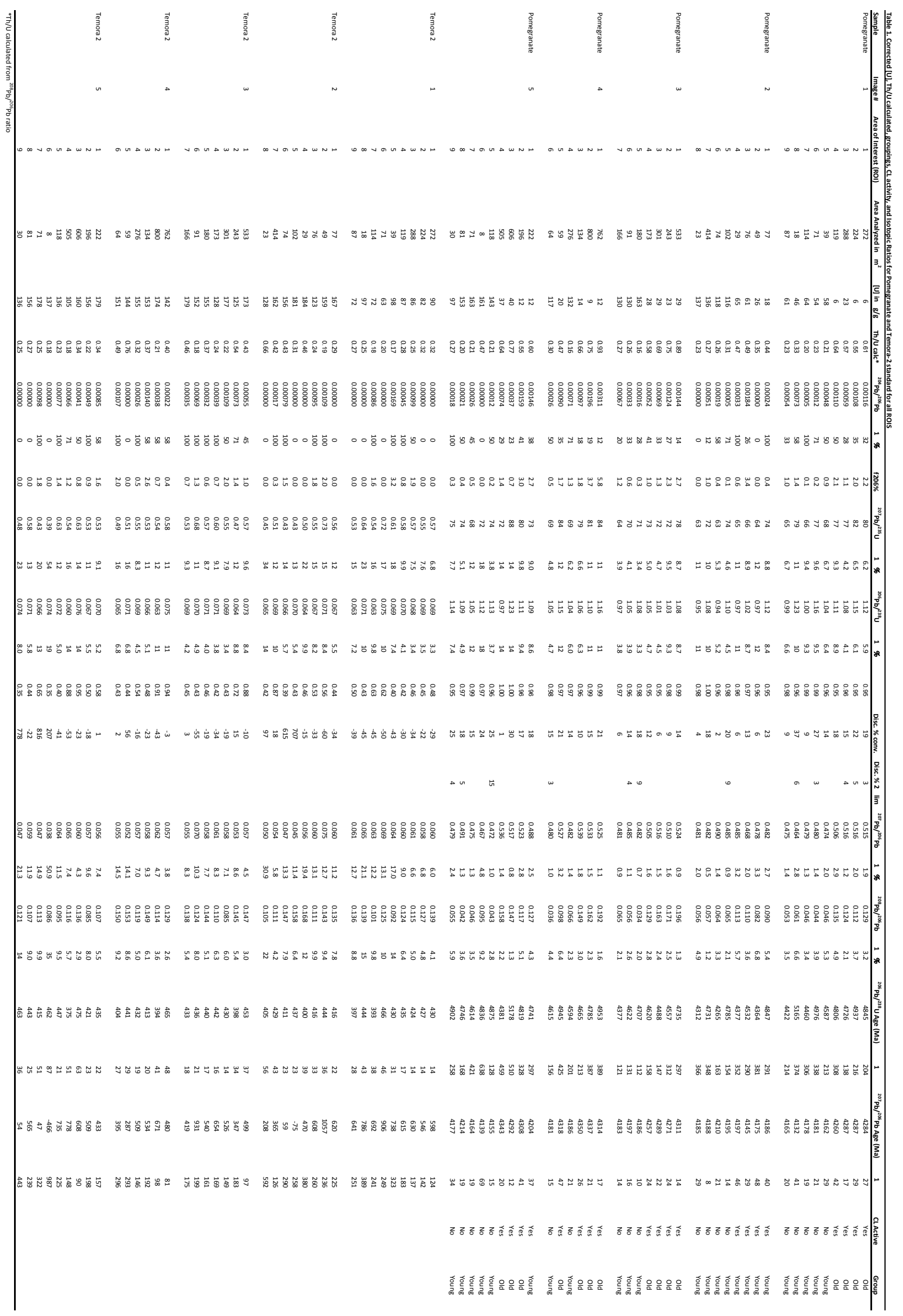

